Preprinted version of the paper published in Journal of Technology Transfer

May 2020

https://link.springer.com/article/10.1007/s10961-020-09795-5 (open access)

\title{
Windows of opportunities for catching up: An analysis of ICT sector development in Ukraine
}

\author{
Anwar Aridi ${ }^{\mathrm{a}}$; Christopher S. Hayter ${ }^{\mathrm{b}}$; Slavo Radosevic ${ }^{\mathrm{c}}$ \\ ${ }^{a}$ World Bank Group, Washington, D.C. 20433, U.S. \\ ${ }^{\mathrm{b}}$ Center for Organization Research and Design, School of Public Affairs, Arizona State \\ University, Phoenix, AZ 85004, U.S. \\ ' School of Slavonic and East European Studies, University College London, 16 Taviton Street, \\ London, WC1H OBW, U.K.
}

\begin{abstract}
Following long-standing calls to investigate information and communication technology (ICT) sector development in lesser-developed economies, this study examines the sector's rapid emergence in Ukraine utilizing a catch-up cycle conceptual framework. Ukraine is a unique case due to the country's location in Eastern Europe, the sector's explosive growth within an otherwise stagnant economy, and related disconnectedness to other economic sectors. This study finds that the confluence of several windows of opportunity spurred an entrepreneurial response among hundreds of firms. However, most of these firms focus on low value-added segments of the ICT global value chain and lack the managerial and technical capabilities to compete globally, much less develop new products and services. As the global ICT services sector evolves, multi-level interventions are required to maintain the sector's growth trajectory and realize the economic and social benefits normally associated the development of a domestically inter-connected ICT sector. In order for Ukraine to secure its digital future, it must seize windows of opportunity in the global and European data economy.
\end{abstract}

Keywords: technology upgrading, software services, outsourcing, organizational capabilities 
* Corresponding author: chayter@asu.edu

\section{Introduction}

During the past 30 years, countries such as India and Israel demonstrated that it is possible to rapidly achieve industrial leadership in the information and communication technology (ICT) sector. Recent research examines the "catching up" of these countries as ICT leaders (Porto et al., 2020), while other studies examine their early emergence (e.g., Arora and Gambardella, 2005a). Catch-up conceptual models enable scholars to explain why and how a sector catches up within a particular national context, the potential result of which can be growing global market share and rapidly increasing per capita income (Lee and Malerba 2017; Malerba and Nelson 2011; Mowery and Nelson 1999).

Catching up in the ICT sector offers unique economic benefits in comparison to others such as steel and machinery. Not only do constituent firms contribute directly to economic growth and employment, but also these firms can help drive the diffusion and adoption of ICT within other domestic sectors which, in turn, can drive national productivity growth (Jorgenson 2005; Wessner et al. 2002). The United States, followed by the so-called 3-I's-India, Ireland, and Israel - are generally considered to be the dominant incumbent countries in ICT while "follower nations" such as Russia, Vietnam, and Argentina have realized their own unique developmental pathways (Arora and Gimeno 2005a; Carmel 2003; Heeks and Nicholson 2004; Suarez et al. 2018).

Ukraine has also emerged as a business-to-business ICT outsourcing hub for U.S. and Europe and thus serves as a recent example of sector catch up. The ICT sector is rapidly growing in Ukraine, accounting for more than $\$ 5$ billion dollars of economic activity, three percent of 
GDP and 10 percent of foreign direct investment (National Investment Council of Ukraine, $2018)^{1}$. The fastest growing market segment in the sector is computer services which grew from $\$ 42$ million in 2005 to $\$ 1.5$ billion in 2014 , making Ukraine the $12^{\text {th }}$ largest computer services exporter in the world (IMF 2019).

Prior to the country's independence in 1991, Ukraine was considered the "brain and breadbasket" of the Soviet Union due to its high levels of agricultural production and sizeable science and engineering (S\&E) workforce involved in the design and manufacture of aerospace platforms (i.e., aircraft and spacecraft), among other types of heavy manufacturing (Schuch et al. 2016). Ukraine's stock of S\&E workforce human capital, among other factors, enabled the country to take advantage of the rapidly growing demand for ICT services driven by the emergence of advanced ICT applications, including cloud computing, machine learning, and virtual reality, among others.

Despite these technical and S\&E workforce legacies, and an otherwise booming ICT sector, the Ukrainian economy is falling behind in several dimensions. While a more in-depth discussion is beyond the scope of this study ${ }^{2}$, Ukraine's waning economy is attributed to several shocks, including post-Soviet transition reforms, Global Financial Crisis in 2008, and conflict with Russia which began in 2014. Per capita GDP has fallen from $\$ 11,910$ in 1990 to $\$ 8,573$ in 2018, total factor productivity has remained negative since 1991, and R\&D and physical infrastructures are gradually deteriorating (Radosevic et al. 2019). ${ }^{3}$

Rapid ICT sector development within the broader context of economic stagnation in Ukraine presents contrasts with ICT emergence in other rapidly developing countries. This study

\footnotetext{
${ }^{1}$ See also Ni-X report, Ukraine: The Nation that Codes:(Accessed February 23, 2020).

${ }^{2}$ See Radosevic et al. (2019) for a recent analysis of the Ukrainian economy.

${ }^{3}$ Ukraine's population has also declined from a high of 52.2 million in 1993 to 44.6 million in 2018. The declining population rate is attributed to out-migration, low birth rates, and relatively high death rates. For more information, see the World Bank Open Data portal (https://data.worldbank.org/, accessed Dec 1, 2019).
} 
thus seeks to explain why and how the ICT sector developed in Ukraine, especially within the country's broader economic and policy context. It does so by utilizing a case study methodology based on an initial in-country evaluation of data availability and quality. ${ }^{4}$ This study draws conceptually from catch-up cycle literature (Lee and Malerba 2017; Malerba and Nelson 2011), supplemented by insights from industrial upgrading (Radosevic and Yoruk 2016). This augmented framework enables explanation of initial sector development by examining "windows of opportunity" 5 for sectoral development and the extent to which firms and the sectoral and policy systems in which they are embedded have responded to these opportunities. Further, conceptualizing sector development as a function of technology upgrading views organizational capabilities as a precondition for firms to scale and upgrade.

This study finds that the confluence of several windows of opportunity spurred an entrepreneurial response among hundreds of Ukrainian firms, several of which have rapidly grown into large, successful global enterprises. However, while the sectoral boom has generated significant economic benefits for Ukraine, most firms lack organizational capabilitiesespecially managerial capabilities - that could enable them to capture value-added segments of the ICT global value chain. Further, there has been little sector or policy response that might enable firms to develop organizational capabilities, much less accelerate the dissemination and adoption of ICT solutions within other sectors to expand the economic impact of ICT sector growth.

The remainder of this paper is organized as follows. The next section introduces the country level catch-up model and firm-level technology upgrading lens and reviews the

\footnotetext{
${ }^{4}$ The study team had difficulty obtaining high-quality administrative data; the quality and accessibility of firm level data in Ukraine has been a challenge for researchers interested in the productivity and innovation dynamics of enterprises.

${ }^{5}$ That is, an country-level opportunity for to take advantage of prevailing conditions to build economic momentum and growth.
} 
empirical ICT sector development literature. Section 3 describes the study methodology. Section 4 outlines the study's findings, including factors responsible for the rapid development of the ICT sector in Ukraine, firm-level perspectives on development, and factors that constrain or enable ICT sector growth. The final section, Section 5, concludes with the study's implications for future research and policy.

\section{ICT Sector Development}

\subsection{Sectoral Catch-up}

To understand the development of the ICT sector in Ukraine, this study draws from the catch-up cycle literature (Lee and Malerba 2017; Malerba and Nelson 2011). Lee and Malerba (2017) define catch-up as the "process of closing the gap in global market shares between firms in leading countries and firms in latecomer countries" (p. 339). The authors posit that different countries may follow different trajectories and position themselves in unique ways in an effort to capture increasing market share and achieve global leadership within a particular market. The catch-up model focuses on the relative sectoral position of countries given cross-country variations in institutions, financial systems, policy, and knowledge base (Malerba 2002; 2004).

According to Lee and Malerba (2017), sectoral systems evolve and change over time driven by technological, demand-oriented, and institutional/policy "windows of opportunity." $\mathrm{A}$ technology window is the emergence of a new technology or radical innovation that provides firms the opportunity to surpass incumbent firms that may be locked-in to existing technologies (Christensen 1997). The demand window refers to opportunities provided by the creation of new and rapidly growing demand at a local or global level. Finally, public policies or other institutional changes constitute a third window whereby governments and public policies

\footnotetext{
${ }^{6}$ These windows broadly correspond to Radosevic and Yoruk (2013) conceptualization and testing of entrepreneurship as the outcome of interaction of technology, market and institutional opportunities.
} 
encourage sectoral development through subsidies, R\&D programs, deregulation, or tax breaks, among other public actions. Windows can be endogenous or exogenous and may occur simultaneously or sequentially, especially in the ICT sector (Lee et al. 2014). Factor endowments, especially low-cost labor, provide a common pathway for latecomer countries to take advantage of windows of opportunity, though this is not sufficient for countries to achieve global leadership within a sector (Lee and Ki 2017).

Long-term catch-up success instead depends on the ability of an economy to undertake technology upgrading within the context of specific industrial and institutional contexts (Ernst 1998; 2001). Discussed in the next two sections, catch-up is specifically dependent on the ability of firms to develop organizational capabilities as well as leverage the sector and policy environment in which they are embedded to support them (Yoruk, 2012; Radosevic and Yoruk 2016; 2018).

Catch-up is especially important in the ICT sector due to both its direct impact on national economic growth and employment as well as its contributions to productivity growth and economic dynamism (Breznitz 2007b; Jorgenson 2005; Wessner et al. 2002). ICT thus embodies characteristics of what Bresnahan and Trajtenberg (1992) term general purpose technologies (GPTs): through its broad adoption, a technology can facilitate economy-wide technical improvements and strengthen innovational complementarities, thus driving productivity growth. ${ }^{7}$ However, if a country or region fails to deploy GPTs—-such as ICTacross society, it will fail to realize their full benefits, including economic and social externalities

\footnotetext{
${ }^{7}$ See also Tassey (1996) who describes the importance of generic technologies, defined as core product and process technologies from which commercial applications are developed through subsequent applied R\&D by competing firms. Generic technologies are undergirded by technology infrastructure, including public-private partnerships, technology standards, and technical tools that can collectively be used by competing firms.
} 
(Perez 2018; Bresnahan and Trajtenberg 1992). ${ }^{8}$ Thus, the catch-up of the ICT sector in Ukraine (or in other emerging economies) must also be viewed in terms of the extent to which it is connected to other sectors in the country and can thus serve as a lever for competitiveness and productivity (Malerba and Nelson 2011).

\subsection{Technology upgrading: Firm-level capability development}

While previous research often neglects multi-level aspects of sector development, an emergent literature frames economic development in terms of firm-level technology upgrading. Firms upgrade by developing organizational capabilities that Dosi and colleagues (2000) define as "know-how that enables organizations to perform and improve its production and service activities' (p. 1). Among different organizational capability types, Yoruk $(2012 ; 2018)$ posits that the upgrading of managerial capabilities is the most critical aspect of firm-level performance. Managerial upgrading includes the acquisition of organizational and managerial methods (e.g., quality management, training, teamwork) and the reorganization of existing managerial activities to facilitate internal and external learning which, in turn, leads to improved firm-level efficiency and effectiveness (Yoruk 2012). Managerial upgrading also underlies the upgrading of other organizational capabilities related to, for example, technology development, marketing, and scaling, given its congruence and complementarities to other processes and incentives (Teece et al. 2000).

Managerial upgrading is especially difficult because there is rarely external incentive to undertake upgrading (Yoruk 2012). For example, in globalized sectors, such as software services, outsourcing clients avoid sharing critical, proprietary knowledge with suppliers due to fears of being displaced by these companies. This means that upgrading is an internally driven

\footnotetext{
${ }^{8}$ According to Bresnahan and Trajtenberg (1992), when dissemination of GPTs occurs through arms-length relationships, development of both vertical and horizontal linkages is constrained, thus limiting the economic and organizational benefits that accrue from their adoption.
} 
process requiring firm to put into place incentives for employees to apply their skills and efforts to organizational objectives and allocate resources for upgrading and growth. A short-term business case rarely exists for these actions because capability development generally entails higher fixed costs and thus places firms at a relative competitive disadvantage (Lazonick 2002a). However, firms that confront and transform market conditions, rather than accepting them as constraints, become innovative enterprises and agents of technology upgrading (Lazonick 2002b).

While few studies examine multi-level sector development, a robust literature examines factors related to capability development among ICT firms. Specifically, ICT firms must assemble a diversified portfolio of products and services to remain profitable through broader economic cycles. ICT services provide stable revenue while the development of new products can provide substantial profit margins (Bonaccorsi et al. 2006; Tanriverdi and Lee 2008; Sanio and Marjakoski 2009; Suarez et al. 2013). Other studies frame success as the ability of ICT firms to develop robust technical, managerial, and marketing and client relations capabilities (Banerjee, 2003; Athreye, 2005; Ethiraj et al., 2005; Chaminade and Vang, 2008b; Li et al., 2010; Lema, 2014; Rose and Furneaux, 2016). Athreye (2005), for example, shows that the success of Indian outsourcing firms hinged on the development of managerial capabilities that enable large software development teams to deliver quality ICT services to firms located anywhere in the world.

\subsection{Systems views of ICT Sector Development}

Following Lazonick (2002b), technology upgrading can also be understood as a dynamic interaction between the organizational conditions of a business enterprise and the policy and sectoral-level environments in which they operate. Technology upgrading also corroborates with 
the catch-up literature's emphasis on windows of opportunity as well as with the role of sectoral and policy environments on the growth of firms (Lee and Malerba 2017). A plurality of studies published since 2000 , especially during the mid-2000s, were motivated by the rapid growth of ICT outsourcing to the Three I's. More recent studies examine ICT development within "follower" countries such as Argentina (Suarez et al. 2018), Serbia (Kutlaca et al. 2018), and Poland (Lechowski 2018), among others. Within this body of research, export-oriented ICT sector development is generally attributed to a maturing market and increasing development costs within Europe and especially the U.S., mirroring the recent conceptual focus on windows of opportunity (Chaminade and Vang 2008b).

For example, in the 1990s, the ICT sector began to modularize, due to the de-coupling of software and hardware, enabling the dissemination of product and service development "chunks" to other firms and countries (Niosi and Tschang 2009). Modularization occurred as clients were seeking increased involvement in ICT application development to customize and improve solution performance (Bonaccorsi et al. 2006; Ojala and Tyrvainen 2006). Further, exogenous events such as the Y2K (year 2000) crisis and adoption of the Euro currency by European Union countries in 1999, accelerated demand for cost-effective ICT solutions (Arora and Gambardella 2005b).

Recent sector growth has been driven by the global search for individual and firm-level capabilities in advanced ICT applications such as cloud computing, data analytics, cybersecurity, and virtual reality (Melo et al. 2016). Specialized software is required to integrate these technologies into functional use. For example, the recent move toward the "servicification of manufacturing" illustrates how disparate manufacturing assets can be interconnected through

\footnotetext{
${ }^{9}$ Servicification is embodied in the Industry 4.0 standard. The term "Industry 4.0 " originated with the German government as part of a national high-tech initiative launched in 2011 to understand the future of manufacturing.
} 
cloud-based machine learning applications that enable flexible production and a high degree of product customization. The servicification trend will not only result in explosive growth of operational data, it will drive further demand for advanced software services and talented individuals that underly these services (Lorenz et al. 2016).

Several systems-level factors described in the literature enabled firms located in other countries and regions to take advantage of these emerging opportunities, thus accelerating the development of a global ICT value chain. The Three I's, for example, possess a talented, English-speaking workforce, high-quality education institutions, and strong connections with their respective diasporas within the U.S. and Europe (Arora and Gambardella, 2005a; 2005b; Giarratana et al. 2005; Chaminade and Vang 2008a; 2008b; Lechowski 2018). While other countries such as Brazil and China encouraged ICT sector development by fostering linkages between ICT and other sectors, such as banking and manufacturing, firm-level attempts at entering international ICT markets have generally been unsuccessful (Carmel 2003; Li et al. 2004; Barney et al. 2009; Melo et al. 2016).

The literature also focuses on systems-level linkages between multinational corporations (MNCs) and local firms, and the related development of country capabilities required for longterm sector growth. In India and Ireland, for example, MNCs helped develop and upgrade human capital stocks through training regimes, the adoption of international quality standards (Giarratana et al. 2005; Parthasarathy and Aoyama 2006), and by outsourcing development and testing work to local SMEs (Arora et al. 2009). In both countries, former MNC employees went on to establish a generation of new ICT startups (Arora and Gambardella 2005a).

Also critical to sector development are horizontal linkages among ICT SMEs as well as organizations and policies that promote their upgrading and collective growth. Kutlaca et al. 
(2018) discuss the role of ICT development organizations that support SME innovation through policies and financial instruments. The Indian National Association of Software and Service Companies (NASSCOM) has, for example, played a critical role in promoting and funding earlystage ICT companies (Chaminade and Vang 2008b; Li et al. 2004; Lema 2014). The Fund for the Promotion of the Software Industry (FONSOFT) was established in Argentina to similarly understand sector challenges and fund activities to upgrade firm technical and management capabilities (Suarez et al., 2018). Other countries have established innovation agencies, some with specific sectoral focus aiming to coordinate and support ICT sector development, though often with mixed results (Aridi et al., 2019).

Heeks and Nicholson (2004) recommend that national governments adopt holistic strategies that emphasize education and skills development, incentives for entrepreneurship, and improving the business environment. The Israeli government, for example, developed several policy interventions to foster ICT sector growth, including R\&D subsidies, linkages with hardware companies, and macro-level business policies (Breznitz 2007a). Firms should also play an active role in curriculum development at universities and training institutes that enables workforce skill development in up-and-coming technical areas such as machine learning and cybersecurity (Li et al. 2004; Arora and Gambardella 2005a; Kutlaca et al. 2018; Lechowski 2018). Governments can also create flexible labor market regulations (Lechowski 2018), reduce regulatory burden (Kutlaca et al. 2018), provide tax breaks and incentives to ICT firms (Arora and Gambardella 2005a; 2005b; Suarez et al. 2018), and use public procurement to accelerate sector development (Arora and Gambardella 2005a; Chaminade and Vang 2008b; Lechowski 2018). 
Interestingly, scholars that examine export-oriented ICT sector development within different countries rarely focus on the relationship between ICT and other domestic sectors. An exception is Arora and Gambardella's (2005a; 2005b) work that describes the economic benefits that accrued to the Three I's as a result of connections that developed between ICT and other economic sectors, such as banking, telecommunications, and manufacturing, though these benefits differed substantially by country.

\section{Methodology}

\subsection{Research Approach}

A case study approach was selected to understand ICT sector development and factors associated with its evolution (Corbin and Strauss, 2008; Eisenhardt, 1989). According to Patton (2002), case studies and other types of qualitative research provide researchers with tools to understand a phenomenon about which little systematic empirical research may exist. In the present case, we found no recent systematic study of ICT sector development in Ukraine. Further, the study will not only contribute to our understanding of ICT sector evolution, it will also highlight how the extent to which its relationship with other economic sectors impacts country-level economic development.

The authors initially worked with two in-country points of contact, a former executive in the Ukraine ICT industry and an expert in Ukrainian political economy, to provide advice and help coordinate the study. The study team, together with the points of contact, constructed a notional interviewee list based on the ICT-related entrepreneurship and management experience, technical knowledge, and involvement in sector-specific efforts to improve related policies. Initial interviewees also provided connections to other contacts that were in-turn important to the study. The mix of participants was guided by the need to address the research objectives above 
and achieve theoretical saturation or replicability (Morse, 2004; Charmaz, 2006). In sum, the study team interviewed 26 individuals, including representatives from Ukrainian ICT firms; ICT industry associations; angel, venture, and private equity investors; customers of Ukrainian ICT firms and a number of sector development experts to inform the study.

\subsection{Data Collection}

Study data collection was comprised of a review of Ukrainian archival data ${ }^{10}$, ICT trade publications, and interviews. Study interviews were conducted during two data collection trips to Ukraine in 2018, supplemented with phone or Skype interviews with customers and sector development experts. In-person data collection was deemed critical given differences in culture and language. Interviews were guided by an open-ended interview template and conducted in English, though at least one study coordinator was always present if translation or clarification was required. Interviews ranged in length from 45 minutes to an hour and a half. During the interviews, respondents were asked several open-ended questions guided by a narrative approach (Polkinghorne, 1988): question responses were followed by clarifying and probing questions to capture important in-depth detail.

The study team took several steps to increase the internal validity of the study. Maxwell (1992) frames the validity of qualitative research in "descriptive" and "interpretive" categories. Descriptive is the extent to which researchers accurately capture the responses of the study participants while interpretive is the extent to which researchers capture their meaning. Following procedures outlined in Creswell and Miller (2000), the study was an iterative process of data collection and analysis followed by validation of these results with interviewees. Figure 1 (below), for example, was created after an initial round of study interviews. The draft figure was

\footnotetext{
${ }^{10}$ Archival data was translated by the points of contact as required.
} 
shared with initial participants for comments, modified based on their suggestions, and shared with subsequent interviewees for comment and revision, if required.

\subsection{Data Analysis}

Interviews were recorded by the study team and subsequently summarized highlighting theoretical implications, including how responses helped construct a narrative of ICT sector and firm-level development as well as general factors that affect this development. Once data collection was complete, as indicated by theoretical saturation, data were coded inductively by the study team, according to procedures recommended by Kuckartz (2014) and Saldana (2012). Specifically, study team members performed an initial round of first-order (open) coding by hand, followed by second-order (axial) data coding to understand the relationship among open codes within and across different types of interviews. A third study team member was available to validate interpretation of the data and resolve any differences in coding. Finally, second-order codes were used to generate study findings, the results of which are reported in the next section. Versions of the derivative study manuscript were shared with three individuals for review and comment.

\section{Findings}

This section presents the findings of our research. Following the sector development literature, the next section (4.1) discusses windows of opportunity to which Ukraine has responded and, on a technology frontier front, it must respond in the future. Section 4.2 illuminates the firm-level response to these windows of opportunity, including a conceptualization of their development. Finally, Section 4.3 discusses the systems level response (and lack thereof) from the perspective of both the ICT sector and government perspective.

\subsection{Windows of Opportunity for ICT Sector Development}


In addition to extant factor conditions, the confluence of two windows of opportunity associated with the catch-up framework, including public policy and changing demand conditions, partially explain the rapid development of Ukraine's ICT sector. Though its education system faces significant challenges, Ukraine nonetheless possesses a highly skilled workforce, a legacy of the country's previous emphasis on training human capital for the aerospace and heavy machinery sectors. While legacy industries are in decline and national investments in education and infrastructure have plummeted (Radosevic et al., 2019), the country nonetheless still retains a robust pool of S\&E-oriented talent.

Relating to policy, Ukraine established in 1994 the so-called FOP ${ }^{11}$ self-employment tax regime to increase reported tax revenues by incorporating individuals operating in the shadow economy while reducing the enforcement burden of the government. ${ }^{12}$ The FOP regime enabled freelancers and independent contractors to pay 5 percent of their income to the government. According to study respondents, the FOP tax not only increased tax revenues, it also helped stimulate entrepreneurial entry in the ICT sector.

Software companies established outside Ukraine by expatriates were the first to take advantage of the country's stock of workforce human capital, low tax rates, and system of flexible employment. ${ }^{13}$ Further, the financial crash of 2008 created a significant demand-oriented window of opportunity. The crash motivated U.S. and European companies in a variety of sectors to look for opportunities to outsource costly non-core business functions such as ICT.

\footnotetext{
${ }^{11}$ FOP, a Ukrainian abbreviation which may be translated as Personal Entrepreneurs Systems or Individual Entrepreneur, is a tax classification that enables self-employment among individuals. Individuals registering for FOP status are authorized to conduct business (services, consulting, trading) and earn derivative profits without establishing a separate legal entity. The FOP status is recognized under Ukraine's Simplified Tax regime originally established in 1994.

${ }^{12}$ According to respondents, a significant number of individuals in Ukraine were involved in the "shadow" or blackmarket economy following the collapse of the Soviet Union. The FOP tax was, according to one respondent, "a realistic policy response, to a difficult situation; the government created a tax that made it more difficult to not file your taxes."

${ }^{13}$ For literature on the role of skilled diaspora in the establishment of outsourcing businesses, see Saxenian (2007).
} 
These companies also took advantage of the FOP tax system to maintain a flexible labor force unrestrained by regulations that accompany full-time employment. ${ }^{14}$

Innovecs ${ }^{15}$, for example, was established in 1994 in Newark, New Jersey (U.S.) by two Ukrainian expatriates to supplement the ICT staff of U.S.-based companies, primarily to financial firms in nearby New York City. When firms began to look for cost savings during the financial crash the company was unable to keep up with demand. Innovecs founders consequently began in 2010 to work with family members in Ukraine to hire software engineers. According to interviewees, high levels of education, skill, and professionalism among Ukrainian software engineers enabled the company to rapidly scale and meet the growing demands of its clients.

Innovecs, along with other early ICT services firms such as Luxoft ${ }^{16}$ and Softserve ${ }^{17}$, demonstrated to global clients the quality benefits and cost savings of outsourcing to Ukrainian companies. Further, the growing demand for ICT talent motivated entrepreneurial-minded software engineers in Ukraine to establish small outsourcing startups. Startup establishment was relatively simple given that entry into international outsourcing markets requires neither large capital investments nor local customers; individuals and firms only need a laptop, a good internet connection, and a working knowledge of English to participate.

The most recent window of opportunity is the aforementioned emergence of advanced ICT applications such as machine learning, virtual reality, and the internet of things (IOT) is accelerating global demand for software services, given that specialized programming is required

\footnotetext{
${ }^{14}$ The FOP system enables firms to take advantage of self-employed individual in a way similar to how Uber drivers might be considered independent contractors. Approximately 44 percent of the 2019 Ukrainian workforce is selfemployed thus illustrating this "Uberization" phenomenon.

${ }^{15}$ See: https://innovecs.com/

${ }^{16}$ See: https://www.luxoft.com/

${ }^{17}$ See: https://www.softserveinc.com/en-us
} 
to integrate these technologies into functional applications. Technology-oriented integration software constitutes the most value-added (and therefore profitable) segment within the sector; firms and countries that can capitalize on these trends will be best positioned to take advantage of their economic benefits. The next section discusses the emergence, market focus, and evolution of ICT service firms in Ukraine.

\subsection{ICT Firm-level Response and Upgrading}

Following the sector development literature, how individual entrepreneurs and firms respond to the aforementioned windows of opportunity determines the extent to which a sector emerges and develops. As discussed, there has been a surge in new ICT startups established since the mid-2000s though some firms developed rapidly, while most remained small. Figure 1 illustrates a phase-oriented development path of ICT firms in Ukraine derived from analyses of study data. Parsing firm-level development into phases does not imply that industrial development follows a predictable, linear process. However, following the sector development literature (Lee and Malerba 2017; Malerba and Nelson 2011; Yoruk and Radosevic 2016), the phases represent critical thresholds important during firm development, including the valueadded activities and the organizational, managerial, and technical capabilities associated with each phase.

\section{$<$ Insert Figure 1 Here $>$}

Specifically, firms in Phases 1 and 2, as defined in Figure 1, provide basic ICT services to companies, including virtual or in-person staff augmentation or department replacement. Freelancers, small startup, and SMEs constitute development phases 1 and 2, though large outsourcing companies, such as Innovecs and Miratech also provide these services. While the government of Ukraine does not collect data that would enable more fine-grained analysis, 
interviewees estimate that Phases 1 and 2 account for approximately three quarters of employment in the ICT sector. ${ }^{18}$ Given the relatively simple ICT functions performed in Phases 1 and 2, few advanced capabilities are required, though firms can be differentiated by their capacity to scale ICT services (e.g., replace the ICT functions of clients).

Firms in Phase 3 are differentiated by their ability to collaborate with clients to design and implement new products and services. These firms not only possess robust technical capabilities in software engineering, they have also developed project and client management capabilities that enable them to manage complex ICT projects and integrate into client teams; these firms developed managerial capabilities that enabled them to progress from Phase 2 to 3. These firms also differ by their relative focus on ICT services in comparison to product development. For example, Innovecs focuses on large-scale ICT service projects but has not traditionally focused on product development. Luxoft traditionally focused on ICT services but has transitioned to developing new ICT products for Mercedes Benz ${ }^{19}$, among other automotive companies, yet continues to provide services. Firms in Phase 3 account for approximately 15 percent of employment in the ICT sector.

The primary focus of Phase 4 firms is product development for direct marketing and sales to consumers and must possess the capability to design, test, conduct R\&D, and provide customer service to do so. Petcube, for example, was established in 2012 in Kiev by three friends who designed a platform technology (i.e., a Petcube) that integrates a camera, treat dispenser, laser pointer, and speakers to entertain anxious pets left at home, linked to artificial intelligence and mobile applications. Petcube eventually moved to San Francisco and has raised several

\footnotetext{
${ }^{18}$ Given that no administrative data is available on the ICT sector in Ukraine, these estimates were derived and validated from during our interviews.

${ }^{19}$ See, for example, https://itukraine.org.ua/en/luxoft-ta-daimler-informatsijnu-platformu-dlya-merceddevelop-aninformational-platform-for-mercedes.html (Accessed December 15, 2019).
} 
million dollars in early-stage funding. Phase 4 firms are often backed by foreign venture capital funding and account for a relatively small share of sector employment (less than five percent), though they can earn significant profits if their product is successful.

Similar to Phase 4, firms in the MNC category focus primarily on product development and perform related R\&D functions. However, these firms are in contrast comprised of large, established multinational companies such as Samsung and Ring Labs (owned by Amazon). Interviewees described these facilities as "disconnected R\&D centers" that enable multinational corporations to take advantage of Ukraine's talent pool. While firms in the MNC category only account for about 5 percent (or less) of sector employment, they can pay significantly higher wages and thus attract the most talented software engineers in Ukraine.

According to respondents, the transition of firms from Phase 1 to Phase 2 is relatively simple. Yet, firms face significant challenges when they attempt to advance from Phase 2 to 3 because they must develop technical and managerial capabilities, including experienced managers and sophisticated management systems, that enable to enable large teams of technically-proficient individuals to co-develop complex products and services with multinational clients. If firms want to achieve Phase 4, they must build additional capabilities in product development, $\mathrm{R} \& \mathrm{D}$, marketing, and customer service, an even more difficult undertaking even for successful, profitable companies. The development of organizational capabilities is difficult given that no short-term market incentives exist for doing so, much less the high fixed costs that come with capability development.

Related, the project orientation of most ICT firms in Ukraine and other institutional factors (FOP tax regime) that enable ICT firms respond to global markets may unintentionally discourage the development of robust organizational capabilities. Specifically, the low-valued 
added nature of client projects combined with the need to protect proprietary solutions have the unintended consequence of creating intra-organizational silos that one interviewee described as "working in caves." In practice, working in caves means that software engineers do not develop a holistic understanding of the overall ICT product or service, much less the overall operations of their own ICT firm.

While Figure 1 illustrates the development of export-focused ICT firms, other domestically focused firms also provide ICT solutions in Ukraine and other Eastern European transition economies. These "localizer" ICT firms, such as 'IT Enterprise', have a working knowledge of the operational and market challenges of the manufacturing, aerospace, and agriculture sectors in Ukraine. According to our interviews, export-oriented ICT firms are largely disconnected from domestic sectors because legacy firms seem uninterested in ICT modernization or, related, (albeit expensive) long-term solution development. Further, working with domestic firms requires developing sector-specific capabilities that take time and would represent an opportunity cost for working in the lucrative global outsourcing market.

\subsection{Systems-level Dynamics}

Though often neglected in studies of sector development, the catch-up model emphasizes the importance of systems-level responses for the ICT sector, including intra-sector and governmental action, just as system development embodies a co-evolution with firm-level responses. The focus on systems is important given that our interviews uncovered evidence of several factors that otherwise constrain the ability of firms to upgrade their capabilities. These constraining factors thus limit the ability of the sector to evolve into higher value-added ICT market segments that may increase its economic impact. 
First, the growing demand for ICT-oriented human capital in Ukraine is outpacing supply driving up wages. These rising wages are making Ukraine increasingly uncompetitive in lowervalue-added ICT market segments as global value-added demand shifts to areas such as artificial intelligence, cloud computing, and cybersecurity. This labor shortage is exacerbated by high turnover rates and the rapid out-migration of talented software engineers, especially in the aforementioned technical areas, to Europe and the United States. According to the World Bank Group - LinkedIn Digital Data for Development, for example, Ukraine is experiencing the highest rates of out-migration among talented software professionals, especially in comparison to countries such as Poland, Slovakia, and Hungary (World Bank Group, forthcoming). Further, education and training institutions cannot keep up with the labor needs of the sector, nor have they necessarily adapted their curricula to reflect the sector's evolving technical requirements.

Sector development has also been limited by the inability of most firms to develop robust managerial capabilities. Part of this difficulty relates to the evolving labor needs of the sector: talented managers are required to build organizational systems that enable firms to meet the large-scale demands of multi-national clients. According to interviewees, because there was little prior demand for business managerial talent in Ukraine during Soviet times, educational institutions do not have a history of developing or training managers.

ICT also faces several business environment-related challenges common to all sectors in Ukraine. Given the importance of product and service development to firm-level success, intellectual property (IP) protection ranks as a critical concern among firms that possess or hope to develop technical and R\&D related capabilities; Ukraine fares poorly in international comparisons of the coverage, duration, and enforcement of its IP protection. Other business environment concerns include excessive or outdated regulations, the paucity of FDI promotion 
activities and policy, high levels of corruption ${ }^{20}$, and an overall lack of government capacity to design and implement supportive public policies (see also Cheney et al. 2017). Finally, broadband internet infrastructure has yet to be built throughout the country thus limiting the ability for other regions beyond the main urban centers (i.e., Kiev, Kharkiv, Odessa, and Lviv) to participate fully in the ICT boom.

ICT firms in other countries firms develop R\&D capabilities by hiring individuals away from MNC R\&D centers or by partnering with research universities and institutes to develop new, enabling technologies. Given the relatively isolated nature of multinational R\&D center and their ability to pay significant labor premiums, there is little interaction with local firms. Further, according to interviewees, Ukrainian research institutions conduct little research relevant to the sector, nor do they possess the interest or capability to partner with firms that might help them develop new products and services.

Finally, as mentioned in the previous section and following Malerba and Nelson's (2011) charge to investigate cross-sector relationships, ICT is externally oriented in terms of organizational, investment, and incorporation and thus disconnected from other domestic sectors in the Ukrainian economy. ${ }^{21}$ Much of this is explained by the lack of competitive pressure among legacy domestic sectors and related low demand for ICT services that might otherwise help Ukrainian firms scale and become globally competitive. As discussed, the emergence of an ICT sector is ideally linked to the diffusion and adoption of digital solutions within other sectors of the economy, otherwise known as "backward linkages." ICT-oriented backward linkages are

\footnotetext{
${ }^{20}$ According to Transparency International Corruption Perceptions Index Ukraine is ranked 120 out of 180 economies. Source: https://www.transparency.org/country/UKR

${ }^{21}$ Radosevic and Wade (2014) designate export-focused sectors and industries isolated from their local economic context as "exclaves".
} 
especially important within the manufacturing and services sectors, accelerating country-level productivity growth (Arora and Gambardella 2005a).

Regarding action to address these opportunities, the largest firms are represented by IT Ukraine Association. Established in 2004, the Association plays an important role in education and policy advocacy for its members, but does not necessarily represent the interest of the smaller firms in the sector (i.e., those in Phases 1 and 2 above), nor does it provide direct assistance to firms so that they might develop competitive capabilities. Similarly, at the time of writing, the Ukrainian government has done little to respond to these system-level challenges likely constraining sector growth and potential gains in productivity and economic growth writ large.

\section{Discussion and Conclusions}

\subsection{Implications for Research}

This study contributes to a contemporary wave of literature on ICT sector development (e.g., Porto et al. 2020) by examining the emergence of Ukraine utilizing a catch-up cycle conceptual cycle lens (Lee and Malerba 2017; Malerba and Nelson 2011) augmented with insights drawn from the technology upgrading literature (Yoruk, 2012; Radosevic and Yoruk 2016; 2018) that prioritize firm-level capability development. Sector development is framed in terms of windows of opportunities and the extent to which firms and systems respond and capitalize on these opportunities to capture market share and thus sector leadership. The Ukrainian ICT sector presents a unique case due to the country's location in Eastern Europe and the sector's recent explosive growth.

By most accounts, the emergence of a vibrant ICT sector in Ukraine is viewed as a developmental success, though the specific path of development contrasts with examples 
discussed in the literature, such as the Three I's and follower nations such as Russia and Argentina (Arora and Gimeno 2005a; Carmel, 2003; Heeks and Nicholson, 2004; Suarez et al., 2018). Specifically, the ICT sector is rapidly growing within an otherwise stagnant economy and is disconnected from other economic sectors, a situation which long term will likely hamper upgrading in ICT sector as well as other sectors in the Ukrainian economy. Further, unlike the experiences of the Three I's, sector development had little to do with the presence and interconnectivity of R\&D-focused multi-national companies (Arora et al. 2009; Breznitz 2007; Giarratana et al. 2005; Parthasarathy and Aoyama 2006). As such, the study contributes to our empirical understanding of ICT sector development and responds to long-standing calls for to expand inquiry to other economic and policy-related contexts (e.g., Kutlaca et al. 2018).

The study also improves the utility of contemporary conceptualizations of sector catch-up by framing firm-level responses to windows of opportunity in terms of technology upgrading (Radosevic and Yoruk 2016; 2018; Yoruk 2012; 2018). When sector development is framed in terms of technology upgrading, the future of the ICT sector in Ukraine seems much less certain, especially given the inability of most firms to develop organizational capabilities among other in-country and global trends that threaten the sector's growth trajectory.

ICT sector development in Ukraine can thus far be attributed to the response of firms to a confluence of several windows of opportunity, including the a priori existence of a talented pool of S\&E-oriented human capital, favorable tax regime, and strong diaspora networks, as well as the 2008 financial crisis which collectively helped to catalyze a robust entrepreneurial response. While these windows were important for rapid sector growth, the development of robust managerial capabilities as well as other related technical and systems capabilities, enabled firms such as EPAM and Luxoft to scale and capture higher value-added ICT market segments. 
However, most ICT firms in Ukraine are relatively small and perform relatively low-value-added functions because they lack these critical organizational capabilities.

As the global ICT services sector evolves, Ukraine now confronts different windows of opportunity, especially the rapid development of a technology-driven software segment, just as its success has created new challenges that threaten the country's competitive edge. Firms located in other countries have come to appreciate the talent of Ukrainian software engineers and are aggressively recruiting these individuals to other regions of Europe and the United States. This continuing out-migration of talent combined with the inability of domestic educational institutions to respond to increasing labor demands has translated into significant labor shortages and rapidly increasing wages. Further, the emergence of low-cost competition in nearby Romania and Bulgaria, among other countries, means that Ukraine is unlikely to remain competitive in low-value-added ICT services. Leaders from business and government are thus left with the question: how might Ukraine best respond?

\subsection{Sectoral and Policy Implications}

While most ICT firms remain profitable, they must also realize that sector success is increasingly determined by their capability to work with clients at scale, co-develop new products and solutions, and eventually develop products and services of their own. For this strategy to be effective, firms must invest in the development of managerial and technical capabilities that would enable them to capitalize on the global trend toward ICT technologydriven integration software. According to interviewees, while awareness is growing many firms nonetheless remain skeptical that capability upgrading is required, given they continue to experience revenue growth and profitability. In that sense, they remain captives of their own 
success. Other firms have the resources and desire to upgrade but face significant structural challenges, especially related to finding and attracting technical and managerial talent.

For the sector to continue "catching up", it must find ways together with the Ukrainian government and other stakeholders to improve both the availability and technical qualifications of human capital, the business environment in which firms operate, and inter-sector connectivity. As mentioned, the Ukrainian government has yet to develop the capacity for policy and programmatic implementation, it can however help improve the operating business environment in the near term. First, the government can respond to recent calls to gradually shift away from the FOP self-employment tax in a way that no longer disincentivizes companies to build scale and hire employees on a more permanent basis. While not unique to ICT, Ukraine can also accelerate its efforts to reform IP law and business licensing and permitting while accelerating structural reforms in the banking and finance sectors.

Public-private partnerships could be one promising approach to address the human capital shortage and related requirement to develop advanced managerial and technical skills. This especially important in areas related to skills associated with emerging advanced technologies such as virtual reality, cloud computing, and machine learning. The largest firms in Ukraine already operate their own ICT training schools and during our interviews indicated a willingness to work with the government to help improve digital skill-building in areas such as data analytics, data management, networking, and programming, at the secondary and postsecondary levels. Emphasis could also be placed on management skills and systems development especially within the ICT context. Such a public-private partnership might include continuous curriculum design and updating, internship and placement programs, and life-long skills upgrading based on evolving sector requirements. 
While leadership and coordination are required from educational institutions, government ministries, and companies large and small, large-scale initiatives are susceptible to failure given the lack of institutional and implementation capacity of government institutions. One promising approach is to establish regional skill-building pilots between government, industry, and educational institutions, a potential example of what Leyden and Link (2015) term public sector entrepreneurship. ${ }^{22}$ These pilots can test the efficacy of skills-related interventions and gradually scale those that demonstrate success. Further, the government might select a research institution (or enable self-selection) for restructuring the goal of which would be to enable individuals and firms to develop advanced technical capabilities and explore other extension efforts that might create linkages between and among small firms (i.e., those in Phases 1 and 2 above) and these institutions.

Finally, government might play a role in helping stimulate demand in other sectors for domestic ICT services. Such schemes have been piloted in other countries with an emphasis on government procurement (Chaminade and Vang 2008b; Lechowski 2018). However, in Ukraine, future efforts to connect legacy sectors with the ICT sector through, for example, vouchers through which firms might purchase ICT services might enable firms to develop integration capabilities in, for example, agriculture, aerospace, and heavy machinery sectors that could be used to enter and compete in more advanced markets in Europe and the United States. Further, by focusing on digitization, cross-sector linkages can enhance the productivity of Ukrainian firms and thus bolster the overall productivity and economic growth of Ukraine.

In sum, changing circumstances and a dynamic global marketplace has created a new window of opportunity for Ukraine's ICT sector. The question remains to what extent will

\footnotetext{
${ }^{22}$ Also see Hayter et al. (2019) for an expanded conceptualization of public sector entrepreneurship that includes public-private partnerships and other forms of collaborative governance that may offer a promising approach to address economic and social challenges in Ukraine.
} 
Ukraine respond to these windows to not only capitalize on these opportunities and develop a vibrant, increasingly advanced ICT sector, but also for the overall benefit of Ukraine's economic future?

Acknowledgements: This paper is based on a research funded by the World Bank Ukraine Finance and Enterprise Sector Recovery and Growth Trust Fund.

\section{References}

Aridi, A., N. Kapil, A. Ytreland, C.S. Hayter, and Y. Li (2019), 'Innovation agencies: Cases from Developing Economies, Washington, D.C.: World Bank Group.

Arora, A., M. Drev and C. Forman (2009), 'Economic and Business Dimensions: The Extent of Globalization of Software Innovation,' Communications of the ACM, 52(2), 20-22.

Arora, A. and A. Gambardella (2005a), From Underdogs to Tigers: The Rise and Growth of the Software Industry in Brazil, China, India, Ireland, and Israel. Oxford University Press: New York.

Arora, A. and A. Gambardella (2005b), 'The Globalization of the Software Industry: Perspectives and Opportunities for Developed and Developing Countries,' Innovation Policy and the Economy, NBER, 5(1), 1-32.

Athreye, S.S. (2005), 'The Indian Software Industry and its Evolving Service Capability,' Industrial and Corporate Change, 14(3), 393-418.

Banerjee, P. (2003), 'Some Indicators of Dynamic Technological Competencies: Understanding of Indian Software Managers,' Technovation, 23, 593-602.

Barney, S., C. Wohlin, H. Ganglan and A. Aurum (2009), 'Creating Software Product Value in China,' IEEE Software, July/August, 84-90.

Bonaccorsi, A., S. Giannangeli and C. Rossi (2006), 'Entry Strategies Under Competing Standards: Hybrid Business Models in the Open Source Software Industry,' Management Science, 52(7), 1085-1098.

Bresnahan, T.F. and M. Trajtenberg (1992), 'General Purpose Technologies "Engines of Growth?", NBER Working Paper 4148.

Breznitz, D. (2007a), 'Industrial R\&D as National Policy: Horizontal Technology Policies and Industry-state Co-evolution in the Growth of the Israeli Software Industry,' Research Policy, 36, 1465-1482.

Breznitz, D. (2007b), Innovation and the State: Political Choices for Strategy and Growth in Israel, Taiwan, and Ireland, Yale University Press, New Haven, CT.

Carmel, E. (2003), 'Taxonomy of New Software Exporting Nations,' The Electronic Journal on Information Systems in Developing Countries, 13(2), 1-6.

Chaminade, C. and J. Vang (2008a), 'Globalisation of Knowledge Production and Regional Innovation Policy: Supporting Specialized Hubs in the Bangalore Software Industry,' Research Policy, 37, 1684-1696.

Chaminade, C. and J. Vang (2008b), 'Upgrading in Asian Clusters: Rethinking the Importance of Interactive Learning, Science,' Technology \& Society, 13(1), 61-94.

Charmaz, K. (2006), Constructing Grounded Theory: A Practical Guide Through Qualitative Analysis, London, UK: Sage. 
Christensen, C. 1997. The Innovator's Dilemma: When New Technologies Cause Great Firms to Fail. Harvard Business School Press, Cambridge, MA.

Corbin, J. and A. Strauss (2008), Basics of Qualitative Research: Techniques and Procedures for Developing Grounded Theory. SAGE Publications, Thousand Oaks, California.

Creswell, J.W. (2003), 'Qualitative Inquiry and Research Design: Choosing Among Five Traditions. Sage, Thousand Oaks, California.

Crewell, J.W. and D.L. Miller (2000), Determining Validity in Qualitative Inquiry,' Theory Into Practice, 39(3), 124-130.

Dosi, G., R.R Nelson, and S. Winter (eds.) (2000), The Nature and Dynamics of Organizational Capabilities, Oxford University Press.

Eisenhardt, K.M. (1989), 'Building Theories From Case Study Research,' Academy of Management Review, 14, 532-550.

Ernst, D. (1998), 'Catching-Up, Crisis and Industrial Upgrading. Evolutionary Aspects of Technological Learning in Korea`s Electronics Industry “, Asia Pacific Journal of Management, 15(2): 247-283.

Ernst, D. (2001), 'Global Production networks and Industrial Upgrading - A Knowledge Centred Approach', East-West Center Working Papers, Economics Series, No. 25.

Ethiraj, S.K., K. Prashant, M.S. Krishnan and J.V. Singh (2005), 'Where do Capabilities Come from and How do They Matter? A Study in the Software Services Industry,' Strategic Management Journal, 26, 25-45.

Gengler, E.B. (2003). 'Ukraine and Success Criteria for the Software Exports Industry,' The Electronic Journal on Information Systems in Developing Countries, 13(8), 1-18.

Giarratana, M., A. Pagano and S. Torrisi (2005), 'The Role of Multinational Companies' in A. Arora and A. Gambardella (eds.), From Underdogs to Tigers: The Rise and Growth of the Software Industry in Brazil, China, India, Ireland, and Israel. Oxford University Press: New York.

Gonzalez, J.L., Melicioni, V, Savona, M. (2016), 'When Linder Meets Hirschman: Inter-industry Linkages and Global Value Chains in Business Services', ISI Working Paper.

Hartner, D.E., Krishnan, M.S., Slaughter, S.A. 2000. Effects of Process Maturity on Quality, Cycletime, and Effort in Software Product Development, Management Science, 46(4): 451-466.

Hayter, C.S., Link, A.N., Scott, J.T. (2019), 'Public-Sector entrepreneurship', Oxford Review of Economic Policy, 34(4), 676-694.

Heeks, R. and B. Nicholson (2004), 'Software Export Success Factors and Strategies in 'Follower' Nations,' Competition \& Change, 8(3), 267-303.

International Monetary Fund (2019). Database Trade in Services. https://data.imf.org/?sk=07109577-E65D-4CE1-BB21-0CB3098FC504 (accessed March 17, 2020).

Jorgenson, D. (2005), Productivity, Vol. 3: Information Technology and the American Growth Resurgence. MIT Press, Cambridge, MA.

Kim, L. (1997), Imitation to Innovation: The Dynamics of Korea's Technological Learning, Harvard Business Review Press, Cambridge, MA.

Kuckartz, U. (2014), Qualitative Text Analysis: A Guide to Methods, Practice and Using Software. SAGE Publications, Thousand Oaks, California.

Kutlaca, D., L. Zikovic, D. Strbac, D. Semencenko and S. Popovic-Pantic (2018), 'ICT Case Study in Serbia: Report on the Innovation Potential of the Software Industry in Serbia,' 
Joint research Centre and European Commission, Science and Knowledge Service, January.

Lazonick, W. (2002a), 'Innovative enterprise and historical transformation', Enterprise \& Society, 3, 3-37.

Lazonick, W. (2002b), 'The Theory of Innovative Enterprise', In Malcolm Warner (ed.), International Encyclopedia of Business and Management, Thomson Learning, 3055-3076

Lechowski, G. (2018), 'Beyond "Development Dependent" in a High-Tech Industry? The Interplay Between Domestic Institutions and Transnational Sectoral Governance in the Trajectories of Emerging Polish IT Firms,' WZB Berlin Social Science Center Discussion Paper: SP III 2018-302, 1-47.

Lee, K. and J. Ki (2017), Rise of Latecomers and Catch-up Cycles in the World Steel Industry, Research Policy, 46, 365-375.

Lee, K. and C. Lim (2001), 'Technological regimes, catching-up and leapfrogging: The findings from Korean industries,' Research Policy, 30(20), 459-483.

Lee, K., T.Y. Park, and R.T. Krishnan (2014), Catching-up or Leapfrogging in the Indian IT Service Sector: Windows of Opportunity, Path-creating and Moving up the Value-chains, Development Policy Review, 32, 495-518.

Lee, K. and F. Malerba (2017), 'Catch-up Cycles and Changes in Industrial Leadership: Windows of Opportunity and Responses of Firms and Countries in the Evolution of Sectoral Systems', Research Policy, 46, 338-351.

Lema, R. (2014), 'Offshore Sourcing and Innovation Capabilities in the Supply Base: Evidence from Software Firms in Bangalore,' International Journal of Technological Learning Innovation and Development, 7(1), 19-48.

Leyden, D. P., and Link, A. N. (2015), Public Sector Entrepreneurship: US Technology and Innovation Policy, New York, Oxford University Press.

Li, M., Z. Lin and M. Xia (2004), 'Leveraging the Open Source Software Movement for Development of China's Software Industry,' Information Technologies and International Development, 2(2), 45-63.

Li, S., J. Shang and S.A. Slaughter (2010), 'Why Do Software Firms Fail? Capabilities, Competitive Actions, and Firm Survival in the Software Industry from 1995 to 2007,' Information Systems Research, 21(3), 631-654.

Lorenz, Markus, et al. 2016. "Time to accelerate in the race toward industry 4.0." Boston: The Boston Consulting Group.

Malerba, F. (2002), 'Sectoral systems of innovation and production,' Research Policy, 31, $247-$ 264.

Malerba, F. (2004), Sectoral Systems of Innovation. Concepts, Issues and Analyses of Six Major Sectors in Europe. Cambridge University Press: Cambridge.

Malerba, F. and R. Nelson (2011), 'Learning and Catching up in Different Sectoral Systems: Evidence from Six Industries,' Industrial and Corporate Change, 20(6), 1645-1675.

Maxwell, J.A. (1992), 'Understanding and Validity in Qualitative Research,' Harvard Education Review, 62(3), 279-300.

Melo, C., R. Ferraz and R.J. Parsons (2016), 'Brazil and the Emerging Future of Software Engineering,' IEEE Software. January/February, 45-47.

Morse, J. M. (2004), 'Theoretical Saturation' in M. S. Lewis-Beck, A. Bryman, \& T. F. Liao (Eds.), The Sage Encyclopedia of Social Science Research Methods. Thousand Oaks, CA: Sage. 
National Investment Council of Ukraine. 2018. "IT Industry of Ukraine: Creating Value on a Global Scale", Kyiv, Ukraine.

Nelson, R. and S. Winter (1982), An Evolutionary Theory of Economic Change. Harvard University Press: Cambridge, MA.

Niosi, J. and T. Tschang (2009), 'The Strategies of Chinese and Indian Software Multinationals: Implications for Internationalization Theory,' Industrial and Corporate Change, 18(2), 269-294.

Ojala, A. and P. Tyrvainen (2006), 'Business Models and Market Entry Mode Choice of Small Software Firms,' Journal of International Entrepreneurship, 4, 69-81.

Perez, Carlota, and T. Murray. 2018. "A Smart Green 'European Way of Life': The Path for Growth, Jobs and Wellbeing." BTTR WP 1.

Patton, M.Q., 2018. Qualitative Research and Evaluation Methods. Sage, Thousand Oaks, CA.

Parthasarathy, B. and Y. Aoyama (2006), 'From Software Services to R\&D Services: Local Entrepreneurship in the Software Industry in Bangalore, India,' Environment and Planning A, 38, 1269-1285.

Piatkowski, M. (2018), Europe's Growth Champion: Insights from the Economic Rise of Poland. Oxford University Press.

Polkinghorne, D.E., 1988. Narrative Knowing and the Human Sciences. SUNY Press, Albany, NY.

Radosevic, S., R. Bruno, C.S. Hayter, and A. Aridi (2019), 'Path for Ukraine's Economic Growth: Technology Upgrading,' World Bank Group, Washington, D.C.

Radosevic, S. and I. Wade (2014), 'Modernization Through Large S\&T Projects: Assessing Russia's Drive for Innovation-led Development via Skolkovo Innovation Centre,' Economics and Business Working Paper 131, Centre for Comparative Economics, University College London.

Radosevic, S. and E. Yoruk (2013) 'Entrepreneurial propensity of innovation systems: theory, methodology and evidence', Research Policy, Vol. 42 (2013) 1015-1038.

Radosevic, S. and E. Yoruk (2016), 'Why Do We Need Theory and Metrics of Technology Upgrading?' Asian Journal of Technology Innovation, 24(sup1), 8-32.

Rose, J. and B. Furneaux (2016), 'Innovation Drivers and Outputs for Software Firms: Literature Review and Concept Development,' Advances in Software Engineering, 51226069, 1-25.

Saldana, J. (2012), The Coding Manual for Qualitative Researchers, Sage: Thousand Oaks, CA.

Sainio, L.M. and E. Marjakoski (2009). 'The Logic of Revenue Logic? Strategic and Operational Levels of Pricing in the Context of Software Business,' Technovation, 29, 368-378.

Schuch, K., G. Weiss, P. Brugner, and K. Buesel (2016), 'Background Report: Peer Review of the Ukrainian Research and Innovation System,' Horizon 2020 Policy Support Facility. Centre for Social Innovation. European Commission. Vienna, Austria

Suarez, D., F. Barletta and G. Yoguel (2018), 'Sectoral dialogue and promotion of innovation in Argentina,' Science and Public Policy, 45(3), 309-317.

Suarez, F.F., M.A. Cusumano and S.J. Kahl (2013), 'Services and the Business Models of Product Firms: An Empirical Analysis of the Software Industry,' Management Science, 59(2), 420-435.

Tanriverdi, H. and C.H. Lee (2008), 'Within-industry Diversification and Firm Performance in the Presence of Network Externalities: Evidence From the Software Industry,'Academy 
of Management Journal, 51(2), 381-397.

Tassey, G. (1996), 'Infratechnologies and economic Growth', in M. Teubal et al. (eds.), Technological Infrastructure Policy (TIP): An International Perspective. Kluwer: Norwell, MA.

Teece, D.J., G. Pisano, and A. Shuen (2000), 'Dynamic Capabilities and Strategic Management' in Dosi, G., R.R Nelson, and S. Winter (eds.) (2000), The Nature and Dynamics of Organizational Capabilities, Oxford University Press.

World Bank Group, Country Private Sector Diagnostic, Ukraine at a Crossroads: Building the Foundations of the New Economy, forthcoming.

Wessner, C.W., D.W. Jorgenson, S. Shivakumar, and C.S. Hayter (2001), Measuring and Sustaining the New Economy: Report of a Workshop, National Academy Press, Washington, D.C.

Yoruk, D. E. (2012), Firm-level Upgrading in Low- and Medium-technology Industries in Emerging Markets: The Role of Learning in Networks, PhD thesis, Science and Technology Policy Studies Science and Technology Policy Research (SPRU) University of Sussex, Brighton.

Yoruk, D. E. (2018), 'Dynamics of Firm-level Upgrading and the Role of Learning in Networks in Emerging Markets', Technological Forecasting and Social Change, 145, 341-369. 
Figure 1: Firm-level Response: Pathways for ICT Development
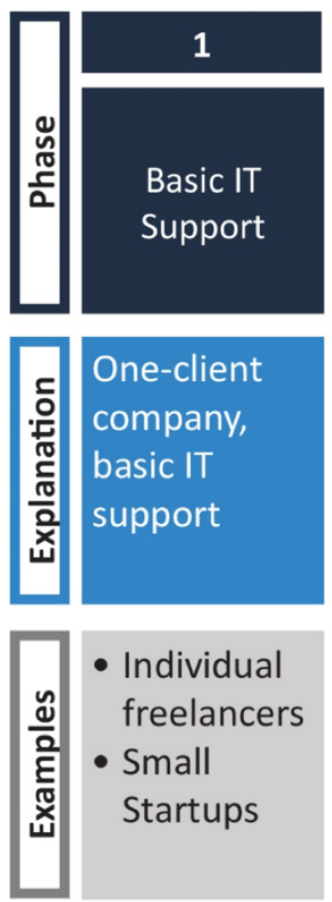

2
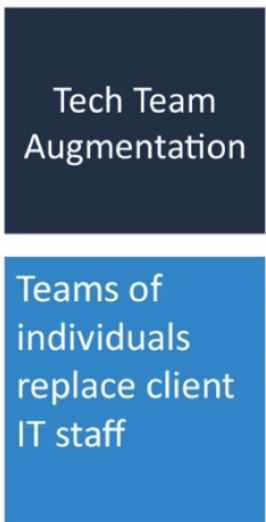

- Miratech

- SMEs

(1)

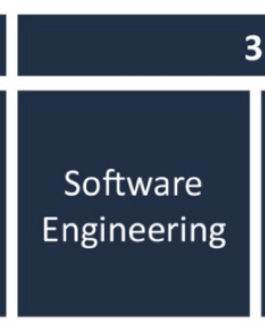

Manages

IT projects

developed

with the

client

- Innovecs

- IT Enterprise

\section{3}

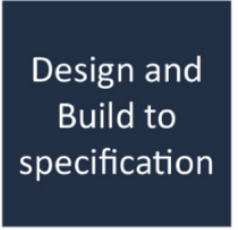

Co-design

products

with client,

digital

services
- EPAM
(UKR)
- Ciklum

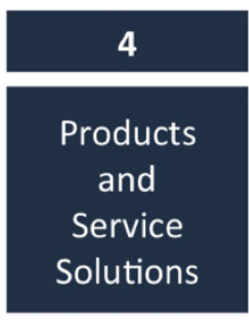

\section{Direct}

to client

products

combined

with services

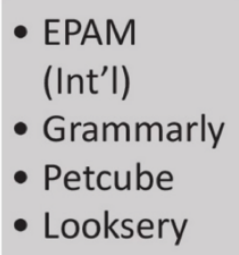

- EPAM

(Int'I)

- Grammarly

- Petcube

- Looksery

\section{5}

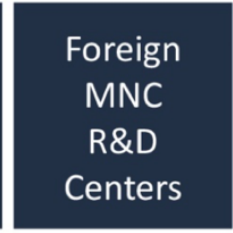

Products

and services

marketed

directly to

client

- Samsung

- Ring Labs

- Playtec

- WIX

Knowledge

Spillover 